\author{
Bartosz Pokorski \\ University of Łódź \\ Institute of Philosophy \\ ul. Lindleya $3 / 5$ \\ 90-131 Łódź \\ bkpokor@o2.pl
}

\title{
SLEEP IN THE CITY. PRIVATE EXPERIENCE OF BEAUTY AND ITS URBAN IMPLICATIONS
}

\begin{abstract}
In my paper I try to trace and understand the reasons for the birth of the $24 / 7$ world as it is described by Johnatan Crary in his book 24/7 Late Capitalism and the Ends of Sleep. He proposes a grim vision of late capitalism in which sleep deprivation and the disintegration of public and private spaces will become a market necessity. My attempt to understand is supported on two other authors. First, Hannah Arendt provided me with an analysis of origins, transformations and somewhat present version of the relation of private and public spheres. Second, Fredrich Schiller delivered an interesting theory on the aesthetic ideal, art, beauty and human experience of beauty. These three analyzes stand as basis for my attempt to present a proposal to overcome the crisis described by Crary and the answer is related to the issue of aesthetic experience of street art in urban space.
\end{abstract}

\section{Keywords:}

Hannah Arendt, Jonathan Crary, Friedrich Schiller, late capitalism, 24/7 world, private and public spheres, experience, repetition, urban space, street art, end of sleep.

What is sleep and why do we sleep? It is not just the opposite to being awake. Immersion in sensations is not dedicated exclusively to the state of wakefulness accompanied by daily experience. During sleep we also experience. From antiquity until the sixteenth century, it was commonly believed that dreams were an integral part of personal and communal life. ${ }^{1}$ The community as such allows sleep to happen. Dreamful, regenerative sleep is possible thanks to our communal life. However, at least since the seventieth century, dreams, and sleeping in general, have been deprived of all their magical-theological and social frame-

\footnotetext{
${ }^{1}$ Jonathan Crary, 24/7: Late Capitalism and the Ends of Sleep (London: Verso, 2013), 105.
} 
work. In the twentieth century, the psychoanalytical movement drew some more attention to the study of dreams. Unfortunately, its strong association with the image of science typical of the turn of the century trivialised the notion of a dream and general sleep experience, reducing it to "a disguised expression of a repressed wish." Any given attempt to fully rationalise sleep and dreams is an attempt too reductive in its nature. Using the light of reason to illuminate the darkness of sleep results in an incorrect translation of the language of a dream into the language of scientific knowledge. The attempt to rationalise sleep is in itself limiting. It simply reduces sleep to a scientifically described biological phenomenon so it becomes deprived of other connotations, i.e. social ones.

Today, due to neuroscience, dreams are disregarded, regardless of their semantic or emotional content. Sleep is explained physiologically so dreams become "a mere self-regulatory adjustment of the sensory overload of waking life." ${ }^{3}$ Now the only acceptable dream is the desire to sleeplessly consume 24/7. Johnatan Crary, in his book, addresses the problem of the $24 / 7$ world, an environment with no retreat, a time of constant continuity, a time without regenerative breaks, and without the need for sleep. 24/7 Late Capitalism and the Ends of Sleep is a contemporary critical attempt to understand the remaking of labour time, ${ }^{4}$ and for me it is the main point of reference.

\section{4/7 CONTINUITY}

The author draws our attention to the eighteen-century painting made by Joseph Wright of Derby, titled Arkwright's Cotton Mills by Night. Crary states that this work of art is an early anticipation of 24/7 time - "a radical reconceptualisation of the relation between work and time: it is the idea of productive operations that do not stop, of profit-generating work that can function 24/7." It shows the disruption of cycles rooted in the natural condition of agrarian life. These changes depend directly on modern notions of productivity and rationality that were a result of the Enlightenment project. They determined the dynamics of modernity.

In the term "24/7 world", the " $24 / 7$ " is not an empty catchphrase. This doubled continuity is an attempt to express the end of rhythmic and periodic textures of human life and a semblance of the social world that in fact is a nonsocial model of mechanic performance. ${ }^{6}$ The $24 / 7$ world is indifferent to the time in which people exist and to their need for sleep, which appears to be

\footnotetext{
${ }^{2}$ Ibidem, 108 .

${ }^{3}$ Ibidem, 110.

${ }^{4}$ Ibidem, 63.

${ }^{5}$ Ibidem, 62.

${ }^{6}$ Ibidem, 8-9.
} 
the last "natural condition" that capitalism has to eliminate. Precisely this, the realm of homogeneous sleepless time, is the goal of late capitalist society. The US Defence Department conducted research on the white-crowned sparrow (Zonotrichia leucophrys) that can stay awake for a week. The aim of this research was to enable soldiers to go without sleep with no deficiencies in productivity. It is not even about sustaining the agent's attention, but more about eliminating sleep and prolonging productivity time. This human disenchantment was aimed at eliminating other primal, natural tendencies such as fear. The vision of the futuristic soldier, with his sleepless, fearless powers will eventually transform into a model of a machine-like unexploitable employee and a constant consumer. Therefore, not only natural environmental circulation, the night and day routine or harmony of ecosystems are disrupted here. We - common, ordinary citizens are being exploited in Crarys' eyes. The author refers to Wolfgang Schivelbusch and his history of lighting technology in which he:

shows how the broad deployment of urban street lights by the 1880s had achieved two interrelated goals: it reduced longstanding anxieties about various dangers associated with nocturnal darkness, and it expanded the time frame and thus the profitability of many economic activities. The illumination of the nighttime was a symbolic demonstration of what apologists for capitalism had promised throughout the nineteenth century: it would be the twin guarantee of security and increased possibilities for prosperity, supposedly improving the fabric of social existence for everyone. In this sense, the triumphal installation of a 24/7 world is a fulfillment of that earlier project, but with benefits and prosperity accruing mainly to a powerful global elite.

The promises given are relatively acceptable, if not desirable. The promised safety, decreased anxiety and prosperity should be available to all. However, we ought to think about what this promise establishes. The changes made by the Industrial Revolution and the overall civilisational progress that have led to this 24/7 time are mainly unjust and harmful for us. We have sold ourselves for cheap consumption. Crary's argument is that we, the common people, not only do not have the promised benefits but also that they, the global elite, evil worldruling whoever, thrive on our exploitation. For this discussion, it is insignificant who these rulers are. It is important to point out that 24/7 time is not cosmic and universal time; it is our time - the time of common, regular, middle-class working people. It is we who cannot afford to sleep, and we who have to stimulate ourselves constantly to stay productive. Our current exploitation is a new one. Regardless of who those they are, we are no longer only alienated from the products of our work but also from ourselves. I think that here is where the problem of experience, taken in the form of falling asleep, might come in handy. On a very speculative level, I suggest that maybe proper coverage of the

\footnotetext{
${ }^{7}$ Ibidem, 16-17.
} 
problem of experience might be the key to at least understand our problems concerning relations with the public and private sphere and its relation to late capitalism, the time to either work or consume. The worst thing to do would be to go back. To take a conservative stance and reject Enlightenment ideas, to throw away the analytical power of illuminated and surveillance mind. Reflective, self-aware consciousness is one of the most important interventions of European thought and the means of its progress. Criticism is a weapon against foreign freedom restrictions, but a self-critical mind is a weapon against our own stupidity, our own inner demons that might come out. The problem that Crary is dealing with, and which I accept as an attempt to critically tackle the problem, is nonetheless not a universal issue. It is somewhat of a first world problem. This struggle, or maybe just an obstacle, can be dealt with quickly in order to pursue other, more universal social problems. I am not saying it is unimportant. It has a crucial meaning for us. However, it is an obstacle that is produced by our way of life, by late capitalist society, and as such is worthy of analysis at least because as members of a rotten Western culture, we need to understand ourselves especially through the symptoms of decay.

What the author defines as sleeplessness, and as "the state in which producing, consuming, and discarding occur without pause, hastening the exhaustion of life and the depletion of resources, ${ }^{\prime 8}$ is connected with the devastation of experience. We are never asleep, but also not fully awake. The 24/7 world abolishes dualities and with the elimination of the night-day cycle, we become distant from the realm of our natural circularity. The foundation of Enlightenment, the natural light of reason (lumen naturale rationis), is now replaced by the artificial light that is said to eliminate all of the penumbras of human life. The enlightened rationality and its programme "wanted to dispel myths, to overthrow fantasy with knowledge" and was aimed at liberating human beings from fear and installing them as masters. Capitalist rationality walks the same path and affects our lives, forces us to consume. It builds an illusion of the whole picture, a semblance of a comprehensive, complete life project. In fact, it lacks its very important component - rest. It is that thing that is taken away from us and something we expect to get back. What will be the promise of such a recovery?

People need a place to regenerate. Crary refers to Hannah Arendt's figures of light and visibility and her description of the necessary conditions for a substantive political life. We need to find balance between bright public activity and the protected sphere of domestic, private life - "the darkness of sheltered existence."

\footnotetext{
${ }^{8}$ Ibidem, 17.

${ }^{9}$ Theodor W. Adorno and Max Horkheimer, Dialectic of Enlightenment: Philosophical Fragments (Stanford, California: Stanford University Press, 2002), 1.
} 
The latter is a place distant form the pursuit of material happiness. Strengthening of self and regeneration stand as complements to the daily exhaustion caused by labour and other activities.

\section{ARENDT'S ANALYSIS AND DIVISIONS}

In Hannah Arendt's analysis of the relation between the public and private realms, she conceptually binds them to action that was typical of ancient Athens. I am particularly interested not in the action that was performed by Greek citizens, but the one that is present in the modern age and has survived until the modern world, and that is opposed to behaviour; an action that can be a excellent standard for the study about an experience. However, it cannot be analysed without mentioning its source, its ideal reference point. There is a strong attraction towards an experience in politics. An engaged and committed citizen might be an object of desire in conservative, liberal or socialist visions. Martin Jay suggests that "the most elaborate and thoughtful theoretical defence of the intrinsic value of political experience" 10 was presented precisely by Hannah Arendt. However, she did not explicitly privilege the concept of experience, and more often talked of action, nonetheless she lamented the vanishing of experience as a kind of political participation. ${ }^{11}$ In her own words, she said that "if we compare the modern world with that of the past, the loss of human experience involved in this development is extraordinary striking." 12 Even in an interview given just before her death, she stated that precisely experience was the subject of her thought. ${ }^{13}$ Obviously, we ought to take a closer look at her work.

It is sometimes not that easy to distinguish the private from the public. In classical Greece, this division was clearer than for us now. The opposition between polis and a family household, activities related to the common world and those related to maintaining life were obvious. For us, they are not, thanks to the interference of the social sphere and consequently mixed meanings transmitted to particular spheres. In order to understand this interference, we need to go backwards, towards this basic division.

The Greeks believed that freedom, as a means to happiness, can only be obtained in the public sphere that essentially "occurred at the expense of the private realm of family and household." ${ }^{14}$ Polis itself did not violate the privacy of citizens, but a minimum of private property was required to participate in

\footnotetext{
${ }^{10}$ Martin Jay, Songs of Experience: Modern American and European Variations on a Universal Theme (Berkeley and Los Angeles, California: University of California Press: 2005), 176.

${ }^{11}$ Ibidem.

${ }^{12}$ Hannah Arendt, The Human Condition (Chicago: University of Chicago, 1998), 321.

${ }^{13}$ Martin Jay, Songs of Experience, 176.

${ }^{14}$ Hannah Arendt, The Human Condition, 29.
} 
communal life. Property was one's own land. In order to determine and decide about the common world, one needed to have his or her own place in it. Private was associated with space. The realm of household was ruled by natural laws that dictated male and female roles, and was determined by the necessities of life. In this sense, there was no place for freedom. On the contrary, in polis freedom was the main principle. If the private and public spheres had anything in common, it was that the first one served as a means to the other, so that the free public, political order could be developed. The two spheres served each other in order not to collapse.

Necessity and determination were pre-political states, so citizens had to break free from those restrictions in order to participate in public action. In the public sphere, free citizens acted and competed over their true individuality. Those who had access to the public sphere were equal and free in a sense that they were able "to rule or to be ruled." ${ }^{15}$ Household head was free only after leaving the private realm. Whereas the private itself was a place of rigid inequality. A citizen's good life was not only better than an ordinary life of a woman or a slave, but it had completely different quality.

It all definitely changes with the emergence of society from the shadowy interior of household. As this emergence blurs the line between the public and the private, roles and meanings of these spheres change. The social sphere remains on the borderline between the public and the private, and it inherits characters of both.

The Greeks valued the deprivational character of the private realm. They respected the hidden character of household and its regenerating properties. A citizen had a chance to be deprived of freedom, openness and discoveredness of his activities. He could take "refuge from the business of the res publica."16 This deprivational character of the private realm might be found in the notion of experience, its liberating force. However, the one who lived only in the private sphere was not fully human. Today's privacy is more opposed not to the public but to the social realm. Society is an intrusion of a special kind. It awakens a certain part of human's psyche by violating the private sphere of household interest and making it public. Modern privacy was primarily dedicated to protect intimacy, thus playing a slightly different role than in antiquity. Jean-Jacques Rousseau was the first to raise the question of intimacy. Its discovery is made "through a rebellion not against the oppression of the state but against society's unbearable perversion of the human heart." 17 The intimacy of heart has no place, so the private could be seen now more abstractly as a person's own inner privacy. Private is no longer associated exclusively with concrete, material

\footnotetext{
${ }^{15}$ Ibidem, 32.

${ }^{16}$ Ibidem, 38.

${ }^{17}$ Ibidem, 39.
} 
space. Intimacy, as privacy, is now an abstract space, a sphere of one's own experience. This attack on intimacy was aimed also at conformism as a crucial element of society. ${ }^{18}$

Society eliminates the possibility of acting in a way that the Greeks acted in the public sphere. Action is replaced with behaviour that equalises people in regard to this behaviour. It imposes certain social roles, creating the right form of socialisation - the secondary socialisation. Also, primary socialisation has its goal in proper education, upbringing and normalising people and their behaviours in society. The name states it openly. Although primary socialisation takes place in family, in the intruded private sphere, it is socialisation nonetheless. Modern behaviour itself, in contrast to individualistic action, is a pre-established set of rules, regardless if we talk about the feudal society of the Eighteen century or a mere social function in our own society. ${ }^{19}$

Modern conformism and equality of behaviour, in contrast to ancient action, form the ideal of modern science of economics. This type of equality is completely different from the one present in ancient Greece, where belonging to a group of a few other equals meant that one had to distinguish oneself constantly. This public realm was reserved for individuality. A presumption that people behave and not act enabled all of social studies to discover and describe the laws governing social behaviour and then predict people's actions. ${ }^{20}$ Statistical laws describe and predict social activities, where large numbers or long periods are involved, only when we treat people as subjects behaving accordingly to social roles and appropriate norms. From this point of view, any creative individual action that would stand in contrast to dominant customs will be treated as a statistical error that remains irrelevant to behavioural sciences. Individualised action can only be noticed in smaller groups, such as in polis. This shows, as Arendt puts it, that joint development of behavioural sciences and society has led to the spreading of the "social behaviour" onto all standard forms of life. ${ }^{21}$ If for the Greeks action was an expression of freedom, and that form, in some way, is absent now, then in what way today can freedom express itself and where?

Arendt recalls two close but not identical phenomena that the term public signifies. Firstly, it is the general public. Everyone who can take part in an intersubjective conversation, in a discourse. Even the most intense forces of intimate

\footnotetext{
${ }^{18}$ Members of society operate on the principles of logic derived from the private sphere of household. They behave as if they are one family, with one interest and one opinion. Before the modern crisis of family, the household head was the keeper of common interest. Family, however, have been absorbed by society. Father's place has been replaced by a sovereign ruler who determines the interest of the nation.

${ }^{19}$ Ibidem, 41.

${ }^{20}$ Ibidem, 42.

${ }^{21}$ Ibidem, 45.
} 
life, such as a trembling heart or deep thoughts of the mind, lead an uncertain existence. Only by public exposure, a potentially existing phenomenon that is seen and heard by us and others can then become an appearance that constitutes reality. Thoughts and feelings must shed their individual and private character and be possible to comprehend in the public realm. Our feeling of reality depends upon the appearance of things and their ability to emerge from the darkness of personal experience into the common realm. Not everything can fulfil this condition. What is unimportant, unworthy of social overview is relegated to the sphere of private. There are, of course, issues such as love, which, according to Arendt, are able to survive only in the private sphere. Love is worldlessness.

The other understanding of the term public is that it means the world itself, if it is common to all and "distinguished from our privately own place in it." 22 The public sphere assumes the private. They are indeed inevitable. The public sphere cannot be associated with what is worldlessness. They are two different orders that have clashed and fought throughout history. For instance, the Christian community is based on brotherhood and bonds of love. In this love, its non-public and apolitical character manifests itself. It emphasises dealing with one's own affairs and treating the engagement in the public affairs as an act of supererogation. However, after the fall of the Roman Empire, we might notice the interference of worldlessness into the public area. The Christian thought has contributed to two quite different phenomena. On the one hand, it has enabled the transfer of worldlessness into the public domain, which has led to the resignation of all things of the world - with the collapse of the public sphere, reality has lost its value. On the other hand, because the world is doomed, we can intensify fun and consume the world. The author concludes that today we are dealing with a similar situation. The remedy or even therapy for this situation would be to ground the public sphere in such a way that it would remain relevant not only for contemporary but also for future generations. ${ }^{23}$ A symptomatic sign of the collapse of the public sphere in modern times is the move towards seeking admiration. That admiration in turn sees its equivalent in money. "Monetary reward is treated as the more 'objective' and the more real" 24 and is daily consumed in increasing quantities.

Arendt claims that the problem lies with the people that have become completely private - they cannot hear and see others. She describes it as the imprisonment of "the subjectivity of their own singular experience, which does not cease to be singular if the same experience is multiplied innumerable

\footnotetext{
22 Ibidem, 52.

${ }^{23}$ Ibidem, 54.

${ }^{24}$ Ibidem, 57.
} 
times." ${ }^{, 25}$ The private sphere cannot be sustained by itself. It makes sense with regard to the multitude of views in the public realm. One phenomenon is being seen by different agents, so it exceeds any intensive perception that is being made at home, in private. Intimate remains one dimensional, whereas the multitude of views in the public sphere preserve the "sameness in utter diversity" 26 and reassures us about the worldly reality. Completely private life would lack any solid feel of reality. Arendt states that "the final stage of the disappearance of the public realm should be accompanied by the threatened liquidation of the private realm as well." ${ }^{27}$ But how to protect both spheres? Of course, this kind of question in such a short text sounds grotesque and naive. I do not pretend to answer it. I am, however, interested in how or where to retrieve what was lost as a result of the changes described by Arendt, and why that which is lost might have such an important value.

The most interesting aspect of her analysis, the distinction of the public and private sphere, is shown in the chapter The location of human activities. ${ }^{28}$ It is primarily not about necessity and freedom, but about which activities should be hidden and which not and why. Two very interesting notions that are exemplary for this issue are goodness and philosophy. As it was said before, the withdrawal from the public sphere into the private one in order to spread good was accomplished by Christianity. Jesus taught by word and deed that the activity of goodness should be hidden, so it would not lose its character - that is "being done for nothing but goodness' sake." ${ }^{29}$ However far-fetched this interpretation of goodness is, it shows some sort of purity of good. Later Arendt states that Socrates also shared this deep intuition but with wisdom. He knew that "no man can be wise, out of which love for wisdom, or philo-sophy, was born." 30 Goodness, good deeds arise from insight that no-one can be really good, except God in Christian tradition. The same refers to wisdom. No-one can be wise; we can only admire it and try to comprehend. This attempt to achieve wisdom happens in an act. In this sense it is practical and suitable for practical application. It is not static but needs to be done. The act itself is not a state of being, not something permanent. It is expressed and exists only as much as it is in motion of being targeted at something (wisdom in this case). Both love of wisdom and love of goodness have in common the fact that they immediately cancel themselves when a person who philosophises or does good deeds views himself as a person who can be good or be wise. We cannot petrify what cannot survive a brief moment of that action.

\footnotetext{
${ }^{25}$ Ibidem, 58.

${ }^{26}$ Ibidem, 57.

${ }^{27}$ Ibidem, 60-61.

${ }^{28}$ Ibidem, 73.

${ }^{29}$ Ibidem, 74.

${ }^{30}$ Ibidem, 75.
} 
However, here the paths of good and wisdom separate. They are both an opposition to the public realm, but in different ways. Good in order to survive, and to some extent this is the main goal for Arendt, must remain in absolute hiding. Whereas philosopher is always in a dialogue - if not with someone else, then at least with oneself. While staying solitarily with one's thoughts, one is never without intellectual company. A person who loves goodness is not solitary but lonely. A philosopher has always his thoughts to lean on. He can remember them or even in some way materialise them in the form of a book, "whereas good deeds can never keep anybody company; they must be forgotten the moment they are done, because even memory will destroy their quality of being 'good'." "' Only the deed can be good. It is not something that we can possess or can be. Good cannot be materialised as a good deed in the world so it cannot be public. This is the key quality of good deeds, they are worldlessness. You cannot memorise them because they are not thoughts. They are acts of will and as such cannot be remembered. If they were remembered, they would cease to be acts and would change into thoughts.

However, there is this very important aspect of goodness that is extremely important for us. The love of wisdom and solitude is in general restricted to few people. Not everyone is a philosopher. Whereas the love of goodness and loneliness is "within the range of every man's experience" 32 and therefore it has a greater impact on the public realm and politics. However, we need to be cautious here. Although solitude and love for wisdom is not accessible to everyone, it can become an authentic way of life. What about love for goodness? With its connections with a religious experience, it is "the experience of love in the sense of an activity" 33 and what is more "like all other activities, does not leave the world, but must be performed within it." ${ }^{34}$ Then "this manifestation, though it appears in the space where other activities are performed and depends upon it, is of an actively negative nature; feeling the world and hiding from its inhabitants. ${ }^{35} \mathrm{We}$ see that it is intimate and personal, however, it is still present in this world - is not fully abstracted from it. It is located in this world.

We can see that they both cause problems. One is not egalitarian, not common enough, and the other is not reflective and intellectual enough. What would be a proper reconciliation of them? Here, I claim, lies the nature of the problem stated previously - how to restore the harmony of the spheres? In this case, the reconciliation of the public and private sphere. In Crary's analysis of the problem of a radical change in continuity of life associated with modernity resounds an old cultural critique known from the beginning of the Enlighten-

\footnotetext{
${ }^{31}$ Ibidem, 76.

${ }^{32}$ Ibidem.

${ }^{33}$ Ibidem, 77.

${ }^{34}$ Ibidem.

${ }^{35}$ Ibidem.
} 
ment that also faced, according to some, similar social cracks. Friedrich Schiller also saw the need to address the problem of the dynamics of modernity. Despite progressive economic and social changes of the era, such as common education or religious freedom, its downfalls were visible for the critic. Within the social realm and the individual disintegration, he tried to create a programme that would lead to a social change. ${ }^{36}$

\section{SCHILLER'S ATTEMPTS AT SYNTHESIS}

In What Is, and to What End Do We Study, Universal History? from 1789, Schiller deliberates on the meaning and purpose of Universal History. He pities the man "who was persuaded to collect ephemeral details for his future vocation, so wretchedly meticulous" and "sees no purpose to his work, but purposelessness he cannot bear." ${ }^{37}$ The author evaluates those actions that are guided by purpose and discusses the work of the philosopher's mind and its ability to synthesise. He also emphasises the superiority of this kind of mind in its tendency not to divide but to combine the efforts and achievements of mankind. Later he glances at his own epoch along with his contemporary man and "equality he lost upon entering the community, he regained through wise laws," or "liberty of the beast of prey to redeem the more noble freedom of the human being." ${ }^{38}$ The author looks at these shifts that are made by civilisation processes. He believes in the power of the Age of Reason and the rational process of humanity growing up and realising its freedom and power. It is guaranteed by history's immanent progress, moving from barbaric to better cultural times. ${ }^{39}$ Culture's role is to allow balance between freedom and laws, and history is the key to our salvation, to ennoblement. Finally, he reveals which facts out of all of the history's matter are valuable and count as elements of Universal History, i.e. these events that had "an influence upon the contemporary form of the world." He is not interested in all of the facts. We are deeply rooted in the present and it is what should interest us. Our problem lives today and from today's world we should seek solutions. History only gives us answers from our own perspective and mainly to solutions to problems - that is their aim. In this early text, the author is quite optimistic about the power of intellectual division.

\footnotetext{
${ }^{36}$ Jerzy Prokopiuk, Utopia i profecja, czyli dwie dusze Fryderyka Schillera in Fredrich Schiller, Listy o estetycznym wychowaniu człowieka i inne rozprawy (Warszawa: Czytelnik, 1972), 5-7.

${ }^{37}$ Friedrich Schiller, What Is, and to What End Do We Study, Universal History? in Friedrich Schiller, Poet of Freedom, vol. II, ed. Helga Zepp LaRouche (Washington, D. C.: Schiller Institute, 1988), 256.

${ }^{38}$ Ibidem, 260.

${ }^{39}$ Ibidem, 261.

${ }^{40}$ Ibidem, 267.
} 
The crisis mentioned earlier diagnosed by Schiller was caused not only externally, by European cultural and political struggles, but also internally - by the anthropological crack caused by the duality of instincts that direct man. ${ }^{41}$ Schiller saw the question of beauty as an anthropological issue that one has to properly address if one wants to regain one's personality and harmony with the world. Schiller, in his later intellectual draft, formulates the ideal of reconciliation of opposites and conflicts by beauty. He tries to restore the antique ideal of a harmonious whole that was killed by the modern. Freedom in the Universal History cannot be manifested until in each of us there is an inner fight between the "individual" and the "universal" human.

In the preface to the Polish version of Letters upon the Aesthetic Education of Man, Jerzy Prokopiuk draws our attention to the effects of Heraclitus' principle, also present in Jung's psychoanalysis, namely the law of enantiodromia - literary running counter to, the struggle of contradictory cultural forces, or psychic, in the case of man whose aim is to harmonise the enhanced element. ${ }^{42}$ In this case, it describes an anti-enlightenment rebellion, disintegration of the society and the individual that came from a disappointment with cold and impersonal rationality and moral formality of the Enlightenment, as well as the bloody effects of the French Revolution. ${ }^{43}$ However, this resistance, and its positive outcome - a programme of reunion with oneself in the aesthetic experience - was possible due to the Enlightenment's attempts to eliminate the irrational. Only through that analytical attempt to liquidate the mythical, unconscious and unknown, could it come back in a sublated form of liberated experience. If this is the way we approach Schiller and his suggestion, and automatic interest in his answer to the problem is aroused.

Intellect is the main prey of civilisation - coal in its technological and political machine. It has become the principle that separates culture from nature and creates new antagonisms that has taken the form of opposing abstracts between which one must live..$^{44}$ Modern man, in opposition to an ancient Greek,

\footnotetext{
${ }^{41}$ Katarzyna Chmielewska, "Podmiot jako utopia estetyczna: 'Listy o estetycznym wychowaniu człowieka' Friedricha Schillera a 'Dziennik' Witolda Gombrowicza,” Pamiętnik Literacki XCV, (2004), 9.

${ }_{42}$ Jerzy Prokopiuk, Utopia i profecja, 25-26.

${ }^{43}$ Ibidem, 10.

${ }^{44}$ Marcin Pańkow, Hegel i pozór, 20. Modern culture possesses intrinsic negativity - it defines itself as continually differentiated from nature, as the kingdom of human reason. This leads to internal disintegration of man, the world of his experience is defragmented. The intellect, Verstand, is the modern principle of rationalisation that separates objective from subjective man, species from individual, general principle from casuistry. It creates antagonisms of abstract opposites, such as nature and culture, laws of nature and moral laws. As a result, the autonomy of the modern man turns out to be illusory. The individual is entangled in the battle of abstraction, losing the disposition to real freedom. This is the condition that Schiller approaches with his programme and the idea of liberation through aesthetic experience.
} 
is "having nothing in his ears but the monotonous sound of the perpetually revolving wheel, he never develops the harmony of his being, he ends by being nothing more than the living impress of the craft to which he devotes himself, of the science that he cultivates." ${ }^{45}$ Schiller gives a diagnose similar to the Marxist critique of alienation and instrumental rationalisation of work. Due to change of modern man's autonomy, one's real freedom is replaced with an abstract one. Schiller shared the mood of disillusionment and consequently modified his positive vision of historiosophy. He turned into aesthetics, especially its experiential character, as a continuation of his reflections. Ancient Greece became his big source of inspiration with its compatibility between sensuality and reason, happiness and virtue. He believed in educational value of culture that could form active citizens and harmonise their contradictory instincts. That was the time and place of beautiful humanity. This vision of antiquity helped Schiller to imagine a bridge between the contemporary crisis and the world of aesthetics. This path could have been the path of progress. It is not about returning to ancestral beliefs but about the development of one's own epoch. This approach extends the current intellectual perspective to a new dimension - the future. It gives birth to a programme, the ideal of a New Greece and future culture. ${ }^{46}$ The past for us is dead. It is the same as with Hanna Arendt - we do not care how really those Greeks lived. How can we fantasise about the division of the ancient private and public sphere, since the culture to which we refer allowed slavery and women's oppression to happen? According to the premise of Schiller's earlier text, history can give us as many answers as we need for our understanding of our contemporary state. In this understanding, we use the Greeks as the ideal, as an intellectual pattern and a common ground for European culture that can be analysed as a fertile source of inspiration. The set of values to which we sign up and which legitimises our actions.

Dehumanisation of society, isolation, soullessness of state are some of the flaws named by Schiller ${ }^{47}$ that are very similar that those listed by Crary and which are caused by the separation of "intuitive and speculative understanding" and the change from "Grecian states, where each individual enjoyed an independent life, and could, in cases of necessity, become a separate whole and unit in himself" to "ingenious mechanism, whence, from the splitting up into numberless parts, there results a mechanical life in the combination." ${ }^{48}$ These phenomena are fully manifested in the intellectual life of the era. The development of science and specialisation of skills have led, on the one hand, to abstract speculation and, on the other hand, to narrow calculating pragmatism. This has

\footnotetext{
${ }^{45}$ Friedrich Schiller, Aesthetical and Philosophical Essays, vol. I, (Boston: Francis A. Niccolls \& Co., 1902), 19 [Letter VI].

${ }^{46}$ Jerzy Prokopiuk, Utopia i profecja, 11-12.

${ }^{47}$ Friedrich Schiller, Aesthetical and Philosophical, 18-19 [Letter VI].

${ }^{48}$ Ibidem.
} 
led to the disintegration of the individuals who become shallow. In contrast to the contemporary culture, each ancient Greek was a worthy representative of all, while maintaining one's own identity.

Schiller not only draws from the Enlightenment but also sketches the intellectual blueprint for The Oldest Systematic Programme of German Idealism. ${ }^{49}$ Marcin Pańków, in his book on Hegel and Appearance, values Schiller's programme in which the author, as a conceptually remaining Kantian determined by the first two Critiques ${ }^{50}$ and thus remaining under the influence of limiting abstractions such as moral law, tries to go beyond it. ${ }^{51}$ Aesthetic judgements associated with the concepts of beauty, as presented in the third Critique, differ from other types of judgement present in the other two Critiques. The experience of beauty cannot be rationalised. It is neither a subject to theoretical objectivity nor an object of practical pursuit. It is an area of different legislation and value. Aesthetics is not directly connected to logical truth or moral right. ${ }^{52}$ It is somewhat a third way. The aesthetic experience is the experience of beauty, which subsequently connects agents with public affairs and ushers us into political freedom. However, from the standpoint of aesthetics, this additional political contexts is a purely surplus value. Freedom is the end and the aesthetic experience is emancipated, understood as itself, separate from ethical, political or logical contexts. The real nature of this experience is indeterminacy by any external boundaries. Pańków also refers to Heraclitus' principle - hen diapheron heauto, and states that the idea of heauthonomy is a new way of free communication between subjects. This would be possible thanks to beauty understood as a pure form without content that would be the experience of aesthetic appearance. ${ }^{53}$ This particular type of experience would be an important component of the author's programme and this would be the embodiment of freedom.

However, in order to prove and justify his programme and statements, Schiller needs to dwell on anthropological considerations and expound the meaning of formal instinct and sensuous instinct. Human as a "mixed nature" has two instincts. The first one, aimed at suspending changes, is the formal instinct. The other one is the sensuous instinct, which is associated with change

\footnotetext{
${ }^{49}$ Marcin Pańkow, Hegel i pozór, 18-19.

${ }^{50}$ Schiller took three main principles from Kantian aesthetic: 1) restriction of the realm of "taste", aesthetic value from the realm of truth (beauty is indisputable) and the realm of good (taste is selfless); 2) a subjective representation of the inner purposefulness accompanying a sense of beauty is considered the main source of distinctiveness of aesthetic phenomena; 3 ) the intermediary function of taste between pure morality (freedom) and pure nature (necessity). Jerzy Prokopiuk, Utopia i profecja, 12-13.

${ }^{51}$ Marcin Pańkow, Hegel i pozór, 18-24.

${ }^{52}$ Ibidem, 25.

${ }^{53}$ Ibidem, 25-26.
} 
and its aim is to search for content. They are both equal, so they need a third mediating and connecting instinct - the instinct of play. ${ }^{54}$ The sensuous instinct is aimed at life, and the formal instinct is aimed at shape, whereas the instinct of play is aimed at lively shape, it seeks the unity of form and content, general and particular, species and individual. Beauty is created in the game, and only thanks to this game an individual can creatively develop. Freedom can only be attained when an individual is complete, when all of the instincts have developed. That is why aesthetics is a humanising tool. This individual development aims to create beautiful humanity, as the ideal of authentic community in the aesthetic state that would combine the elements of dynamic physical force with the ethical state of law and obligation. Therefore, beauty plays a double role. Firstly, art and beauty are used instrumentally in a programme of aesthetic education that raises new citizens of the new culture. Secondly, in a theory of aesthetic ideal, art and beauty play a role of the highest value and norm.

Freedom is accessible only in the dialectical fight, thanks to the instinct of play. ${ }^{55}$ This instinct of play in itself is a contradictory movement - it is a sublation of two excluding forces, instincts limited to one instinct, but at the same time it is an empty gap between those two. This ideal state of being, the one and the other at the same time, is the "idea of his humanity; accordingly, it is an infinite to which he can approach nearer and nearer in the course of time, but without ever reaching it." ${ }^{, 56}$ It is the unreachable but we ought to reach it in order to be human. It represents the full humanity that essentially, from the common point of view, is unreachable.

After the diagnosis of the fundamental crack in human nature, the author proposes a project of keeping man unsettled and uncertain. Just as if man needed to be occupied with cultural upbringing, so that he did not notice that the programme of human education cannot be realised. "It is only in conformity with this idea that he is a man in the full sense of the word; but he cannot be convinced of this so long as he gives himself up exclusively to one of these two impulsions, or only satisfies them one after the other." ${ }^{, 57}$ However, then we know that "but if there were cases in which he could have at once this twofold experience in which he would have the consciousness of his freedom and the feeling of his existence together, in which he would simultaneously feel as matter and know himself as spirit, in such cases, and in such only, would he have a complete intuition of his humanity." ${ }^{58}$ By nature, this programme is quite exclusive. It depends, however, on which moments of this theory we will put more emphasis on. If we focus our attention on the attainment of the unrealistic

\footnotetext{
${ }^{54}$ Friedrich Schiller, Aesthetical and Philosophical, 50-52 [Letter XIV].

${ }^{55}$ Katarzyna Chmielewska, "Podmiot jako utopia," 9.

${ }^{56}$ Friedrich Schiller. Aesthetical and Philosophical, 50 [Letter XIV].

${ }^{57}$ Ibidem.

${ }^{58}$ Ibidem, 50-51 [Letter XIV].
} 
ideal, instead of a free play that can actually be realised, even if only for a moment, in the aesthetic experience, it will become less interesting for the intended purpose.

Nonetheless, cultural difficulties are also necessary for the progress of the total. Although the social division of labour prevents citizens from multidimensional development, society as a whole can participate in the progress of humanity as a whole. This in turn enables the creation of an environment (the state) in which citizens can finally flourish. Beauty, as the third force, can harmonise and mediate between the multiplying extreme contradictions, and create one harmonised whole. Beauty is a king regulator, an adjuster, because "the sensuous man is led to form and to thought; by beauty the spiritual man is brought back to matter and restored to the world of sense." $" 59$

Only art can sustain such a perfect unity of contradictive elements as matter and spirit or becoming and finished. Through art and its beauty, the true nature of humanity reveals itself. The sphere of art, appearance and play, is gaining fundamental importance for freedom. It becomes a space in which the complex duality of man is fulfilled. Beauty is therefore a synthesis of formal and sensual instinct. ${ }^{60}$ Art here is beautiful appearance. Artificialness and appearance of art separates it from reality, and this separation gives art its autonomy. However, it is not just an innocent fantasy or a daydream; it is an area of intentional human activity, a gesture and form that others burden with meaning. Art appears as a semblance, a game that is played among and by people. It makes us what we are in essence: "only completely a man when he plays." Appearance is no longer just a semblance, it is the purpose now. Art gives people their humanity back, makes them free and united with all of the humanity. ${ }^{62}$ This internal path of transformation is subjective, after Kant's critical philosophy, the point of application is transferred onto the subject, and the individual, everyone must gain self-awareness of their humanity. Furthermore, it is dialectical by nature. It requires continuous movement between form and expression, individual and common, and so on. Choosing citizenship, people lost their natural unity and unified nature. Intellect cracked human open and only something as artificial as art can mirror human condition and freedom.

The choice of society, even if it is made for us before we were born, requires a certain moment of suspension. Natural automatism no longer applies to us fully. "The transition from the passivity of sensuousness to the activity of thought and of will can be effected only by the intermediary state of aesthetic liberty." ${ }^{63}$ According to Schiller, it is a state of real liberty and ease. It is free

\footnotetext{
${ }^{59}$ Ibidem, 64 [Letter XVIII].

${ }^{60}$ Katarzyna Chmielewska, "Podmiot jako utopia," 10.

${ }^{61}$ Friedrich Schiller, Aesthetical and Philosophical, 56 [Letter XV].

${ }^{62}$ Katarzyna Chmielewska, "Podmiot jako utopia," 11.

${ }^{63}$ Friedrich Schiller, Aesthetical and Philosophical, 81 [Letter XXIII].
} 
from intellectual and moral considerations. It is an emancipated and an emancipatory state. It is emancipated from the narrow circle of natural ends ${ }^{64}$ and it emancipates people from their dependent condition of serving the law of nature and arises them to rational ends. To achieve the moral state, to raise to it, one has to practise freedom, while still being present in the world. Before one attains what is higher, one must be able to balance between the temporal and the beyond. One must be able to play with it and get into one's "physical destiny with a certain liberty that belongs only to spiritual nature, that is to say, according to the laws of the beautiful." ${ }^{, 65}$ The task of culture is precisely that, the aesthetic practice in freedom. This cultural education serves a particular purpose. To adopt to the moral state, one must achieve the aesthetic state as a progression from the physical state. A person has to transcend his or her own individual existence towards the common, universal one and break free from natural, local, limitations. Man must realise his commonness, must gain self-awareness. This is happening thanks to the instinct of play aimed at art, thanks to the aesthetic experience.

However, this abstract and idealistic concept of beauty is pragmatically unrealistic, it cannot access the common domain. This is a strong argument against the theory which, as a project, is supposed to be realised. This concept remains as the inaccessible ideal for two reasons. Firstly, "the highest point to which experience can reach will consist in an oscillation between two principles, ${ }^{, 66}$ so the very nature of human experience in general cannot match the ideal state. An idea is a static unity whereas an experience is dynamic movement between different phenomena. Then again Schiller finds an answer to this problem. There is a way to get closer to this single ideal of beauty. To be moral, we do not only have to conceptualise virtue. What is more, an active man has to practise virtues and "the business of physical and moral education is to bring back this multiplicity to unity." ${ }^{67}$ Through practice and repetition, the particular aspect of something - a good deed - becomes closer to the ideal - good itself. The same is true for beauty - "the business of aesthetic education is to make out of beauties the beautiful." ${ }^{68}$ The essence of aesthetic education is not art history knowledge, not facts, dates or information on artists. It is the repetitive experience of art, enhancing sensitivity to it, and exposure to beauties. This would be the practice of aesthetic - a recurring experience.

Then again, this interesting solution of forming cultural citizens, which we would gladly accept, generates another social and pragmatic limitation that

\footnotetext{
${ }^{64}$ William F. Jr Wertz, "A Reader's Guide to Letters on the Aesthetic," Fidelio 14, no. 1-2. Spring-Summer (2005), 101.

${ }^{65}$ Friedrich Schiller, Aesthetical and Philosophical, 83 [Letter XXIII].

${ }^{66}$ Ibidem, 58 [Letter XVI].

${ }^{67}$ Ibidem, 59 [Letter XVI].

${ }^{68}$ Ibidem.
} 
urban and common art could overcome. The problem here is the exclusive character of art itself. The abstract subject-object relation described by Schiller, as a form, presents itself interestingly. However, its practical application is irrelevant for those who Crary is writing about; namely for us - late capitalism middle class masses alienated not only from the product of our work but also from ourselves in the private consumption leisure time. It has low accessibility. Art might seem to have a high rate of incomprehensibility or seem to be covered by the inaccessible museum walls. Art might be seen as deeply entangled in the inaccessible art world, its value might be reduced to images depicting national events or simply uninteresting and overintellectual. This is an issue not only of material walls of museums, but also of our inner walls that we project on the art itself. Stronger are those borders that are in our minds as ideologies - our own fear of art's inaccessibility and its bourgeois status. Art in order to be embraced might need to directly interact with the common people. High and low art can be as obsolete as not useful. Talking about art, I want to talk about art for the ordinary people and by that I do not understand a consumerist product presenting itself as art. I think of something that can be an object commonly available which, at least thanks to its location or the context of occurrence, enables the recipient to attempt a free aesthetic experience.

A stronger argument against Schiller's theory is the fact that it is too metaphysical $^{69}$ and it might be exclusivist when the object of liberation (art) is inaccessible. On the grounds of Crary's analysis, I may have evidence why Schiller's ideas might work, despite their speculative assumptions.

\section{RECAPITULATION OF SLEEP}

Let me return to Crary's critique and to Joseph Wright's painting. The factory does not fit into agricultural areas, not only aesthetically. The organisation of working time that until now depended on agriculture, the cyclical nature of periods of work which determined the time of day, does not fit into the capitalist ideal. It must constantly accelerate and remove all environmental and social boundaries. First, capitalism breaks contact with the earth - the factory is a modern "autonomous space in which the organisation of labour could be disconnected from family, community, environment, or any traditional interdependencies or associations. ${ }^{, 70}$ Agriculture has been industrialised retroactively. Once capitalist order is established, it is imposed on everything else.

\footnotetext{
${ }^{69}$ As it involves unverifiable and strongly speculative presuppositions about human nature and it presumes that its theoretical analysis and its solutions, when applied in practice, will solve the problem diagnosed with this theory.

${ }^{70}$ Jonathan Crary, 24/7: Late, 63.
} 
It wants old forms of space to become independent from natural conditions. It wants its own 24/7 world, with 24/7 time. Painting depicts primarily the standardisation of time that exceeds the natural and social constraints, not the manufacturing rationalisation.

Capitalism requires constant duration. It cannot tolerate any breaks. Only by minimising their number, it can generate surplus value. ${ }^{71}$ Sleep disrupts this totality. It creates a dangerous leak that can possibly counteract capitalist progress. This break in continuity is needed in order to achieve self-consciousness. It is visible very well in Schiller's division of poetry. The basis of this typology is the recognition that all poetry tries to express "nature" and the ways to experience it. The first type is "naive" poetry that arises directly from nature. The other one is "sentimental" poetry that comes from a feeling of loss after a broken connection with nature. The first type represents ancient poetry and the other one represents modern poetry. ${ }^{72}$ Scientific and cultural progress is the reason for the lost contact with nature, the loss of directness with it. However, if the lost ancient holistic approach is to be treated as the ideal, it can be treated as a guideline, as a direction, as an end to the projected action into the future. The maxim "back to nature" becomes a forward-looking project. Forward into the ideal. The ideal is the Greek antiquity - the world of unity of nature, people and gods. That is how the beloved nature and naive poetry are being overcome by a superior, progressive and improved notion of sentimental poetry. There is no way back to nature. It is only possible to restore the relation with it, but that will always be a reconstructed relation. After the scientific revolution, we see that this direct connection is lost. We do not know, however, whether the dream of that relationship was not born out of that rupture. It does not matter. We are interested in today. In order to restore the relation to nature, the author first needs to understand that he lost it, even if the loss was only illusory. Then it needs to be restored as the ideal. However, the ideal is something unachievable. Between the lost nature and the ideal nature, there is an attitude towards nature expressed in sentimental poetry - conscious of the impossibility of realising this relationship, conscious of its limitations, reflective and self-aware, not ancient but modern.

The same might be done with all of the lost objects such as action, sleep and so on. I claim that an experience might be the answer here, and particularly its urban presence and reenactment. First, however, we need to have a look at its structure and its relation to sleep. Since the nineteenth century social control has been relatively mastered. Methods of behavioural regulation help to absorb more and more spheres of human life. It happens in state institutions - school, prison, modern armies, office spaces - as well as in the private sector - corporations.

\footnotetext{
${ }^{71}$ Ibidem, 62-65.

72 Jerzy Prokopiuk, Utopia i profecja, 30-34.
} 
However, there still remains one unauthorised, problematic sphere of personal experience. Crary mentions everyday life as the last un-administrated island outside work, conformity and consumerism. ${ }^{73}$ It may be the last place where sleep can retain its "natural" character. It would be a skansen, an open-air museum, where the pre-modern forms of experience, such as sleep, could exist. We should look at those forms of experience. Habit and repetition have always been the most important forms of everyday life. ${ }^{74}$ The cyclical nature of everyday life is organised around fixed elements. I believe that this is the most interesting trait of everyday life, of the domestic sphere - repetition. Repetition is a phenomenon regularly, from time to time, repeated, so it enables us to clearly distinguish recurring elements. Homogenic time of continuity makes everything the same.

Because various forms of electronic activity and exchange have gotten omnipresent, everyday life is no longer an unstoppable barrier for the 24/7 world. Every area of life imposes the constant need to exchange information via technical devices. Attention-based economy blurs lines between the personal and the professional, between entertainment and information, and even advertisement and information. Television was the first that flattened our experience, by evolving the realm of our praxis into undifferentiated passivity. ${ }^{75}$ The author suggests that "television was only the first of a category of apparatuses with which we are currently surrounded that are most often used out of powerful habitual patterning involving a diffuse attentiveness and a semi-automatism." It is a part of strategy of power which aims to create "states of neutralisation and inactivation, in which one is dispossessed of time.",77

The 24/7 need for our "online presence" forces us to create a whole range of artificial personalities. That by itself is not a negative thing. I do not want to preach for true, authentic personality, a place where one can stop pretending and just be. This creation of ourselves might be even a bigger truth than the mystical, natural true self. However, the issue here is that we are obligated to create these artificial personas and that they are arranged according to norms designed or required by the $24 / 7$ world. This might be disorganising for one's personality. The problem is not only in the tool. Of course, the very conditions in which we find ourselves are such that they create the environment which forces us to accept the 24/7 world. However, by not sending e-mails or stopping googleing things up, we will not create conditions for a revolution. Our first self-conscious act would be to notice and then somehow break our own alienation.

As I stated before, if we want to reclaim what is lost, we need to look at the logic of losing it. The 24/7 world with its continuity tries to disrupt natural

\footnotetext{
${ }^{73}$ Jonathan Crary, 24/7: Late, 68-70.

${ }^{74}$ Ibidem, 69.

${ }^{75}$ Ibidem, 81.

${ }^{76}$ Ibidem, 88.

${ }^{77}$ Ibidem.
} 
circularity and regeneration of sleep. All of them are associated with the domestic sphere, everyday life. The characteristic trait of domestic sphere is repetition. However, if the private sphere, as an experience-friendly environment, is being constantly attacked by the $24 / 7$ world, then the question emerges: "Where and when can we experience?". Without even precisely knowing what an experience is, we can say that as part of the private sphere, it has also a repetitive character. A particular experience is not a full experience yet. As part of everyday practice, it has to recur repeatedly in order for a person to know better the object of experience. This knowledge, boredom even, can be a prelude to self-reflexion and to the freedom of play. From this standpoint, it does not matter if the knowledge about the object, or maybe more specifically of its appearance, is true or not. Here we do not care about true or false statements about reality. We are free from the logical truth or moral right. We are liberated in this free action. This creates a moment of suspension. If the world becomes the 24/7 world of constant continuity, we can break this continuity with worldlessness suspension - an act of free experience, free from the 24/7 world. This, as an act which stands in contrast to determined behaviour, would be our dreamt rest. Unfortunately, this still does not answer the question about where we could reenact this experience.

Crary's analysis of sleep is helpful here. The modern notion of sleep, except the sleep itself, also includes the interval just before the sleep - the suspended time when we wait to fall asleep, but we do not hurry. A gap moment without any other purpose. When we wait with no particular aim in waiting, we truly experience. It happens every day. It is a habit and a repetition that not always looks the same. Sometimes we wait for sleep to come, sometimes we immediately fall asleep, and sometimes we think too much and so on. This is the ideal. Not the lying in bed, but just this form of being here and now, half aware and half "I don't care" game with oneself, open to alternative versions of this experience, with the knowledge that this will occur repeatedly. A state that would be similar to meditation, if not for the active side. The end of experience has to be the same as the end of sleep. It has to be a moment of regeneration. But this regeneration has a particular meaning, namely regeneration from the $24 / 7$ world.

In order to answer the question "Where and when can we experience?", I have to recapitulate what has already been said. Crary's problem is to fight the faceless establishment of late capitalism that interrupts our relation with natural circularity through the $24 / 7$ world of constant continuity that eliminates sleep. Not only sleep is disrupted, but also the communal life. The author intertwines these two. The question here is about the end of sleep - will it end definitely and what is the end of sleep? Arendt's analysis is focused on the idea of public action and its fall in the modern society. She presents an analysis of the ancient Greek division into the correlated public and private realms that stands as the 
ideal based on which we could learn what it means to be free and how to act as a free agent in the public sphere. She presents a description similar to Crary's of the disintegration of civic action that is the result of the interference of the social sphere. We seek the restoration of the harmony of spheres. She also provides a very interesting analysis of types of private actions hidden from the public light. These acts are an expression of free will, but can be still hidden as something intimate. Schiller synthetic endeavours also involve attempts to restore the unity of what the enlightened mind has divided. He tried to restore the balance (even if it has never really existed). The author sketches a programme of experience of beauty by aesthetic experience, an idea based on Kant's resolutions and the Greek ideals of beautiful humanity. Its intention was, amongst others, to achieve freedom in the dialectical fight, thanks to the instinct of play. Art would be the object of such a practice of aesthetic experience and a contribution to cultural education.

To answer the question, I will try to draw lessons from these authors. We can take the idea of activity practised in the privacy of intimacy. This act would have to be in its form a mixture or something intermediate between love of/act pointing at wisdom and love of/act pointing at goodness. The best would be an oscillation between these two - sometimes it would be an inexpressible lonely experience and sometimes it would be an intellectual speculation, conclusions that can be analysed as a reflexion on memories associated with the former and about it, even if it is misinterpreted. The movement here is the key. But this sometimes requires repetition. On different occasions, we can act differently. But where is that big reveal? I claim that through the repetition of experience, a third one might occur. That is the one of which Schiller was talking about. The instinct of play can wake up when boredom of the object arrives. A well-known object that is nonetheless present in the repetition appears in front of us and challenges us with its shape, size, colour, symbolism, whatever we can make of it. We play with its appearance. When we get bored with it, we can study it more, criticise it more, like it more, find its beauty. We are free here in the moment. It has no moral or logical meaning. It might have no meaning at all if not for the experiential value. In the context of this text - a major one. This would be a true freedom. Subjective freedom from the $24 / 7$ world, with no surveillance apart from one's own.

But who could do that? It sounds very complicated and exclusive. Who would have time and resources to do that? These are partially the obstacles I have mentioned with Schiller. How an abstract and idealistic concept of beauty can access the common domain? Of course, through practice and experience of art, we enhance sensitivity to it. But where can we repeatedly experience this object - art? Art might seem incomprehensible, beauty too difficult. It might be so only with an already elitist vision of art. It is not the fault of the art itself, by of the ruling ideology. However, I claim that an experience is a democratisation 
tool. A common experience is the common ground for dialogue and communication. On this ground, we can consider impressions of common experiences. This would agree with an idea of heauthonomy, mentioned by Pańków, as a new way of free communication between subjects. I am talking here again about something I called common art. Schiller's speculative subject-object relation might work with the change of the character of the object. If it was commonly accessible, it might open us up to the aesthetic experience as described above. The problem is not that we do not like art. The problem is that we might be intimidated by art and do not want to experience its beauty. We might need here the law of enantiodromia and move in the opposite direction. Through the experience of beauty in the object we recognise it as art.

This object, not yet art, can be potentially experienced in natural conditions of the working middle class - in the city. Street art in the city can be daily, repeatedly experienced and this is a big chance for us. Here we might save what Crary is afraid to lose. In this case, we have lost the connection with natural circulation, we are losing sleep, so we can regain it through its form - repetition - but with regard to that which has caused the separation - industrialisation and urbanisation. We do not have to lose the gains of civilisation, just reinterpret them. The city is the reinterpreted nature. Art, such as murals, graffiti, urban sculptures, parks, or architecture, constitutes the objects of our common and aesthetic experience of beauty. They are the objects helpful in our escape from the $24 / 7$ world. This is my answer - art in the public space - a socially shared space of common experience; a place of urban form of experience, where the total alienation is visible for anyone. Nowadays people tend not to see the world around them. The rebellion that we need now is not a rebellion against authority or the state. A very important rebellion is the rebellion against ourselves. Harm is done - consumerist values are already internalised; the logic of 24/7 has become our own. We need to learn how to escape from that.

Of course, the problem of whether art in urban space draws attention to itself remains, but this is another issue. Art in urban space, in the context of what I have previously said, should provoke. Not in the sense that it is supposed to be vulgar or controversial. On the contrary, all forms of correspondence of urban art with a given place, street, community, or town are indicated. All the attention-grabbing techniques used by consumerism are well known, but they are not what we should aim at, if we do not want to end up in the 24/7 world. The object of aesthetic experience should be out of that world, should be matching and occupying our attention. If Crary's and Arendt analyses are correct, and I interpreted them correctly, the action that we want to provoke has to be out of the consumerist realm. This attempt is to combine or harmonise, as far as we can say so, the public and private realm. This is not a full programme, but a proposition. Going further, perhaps other, even institutional, actions should be taken to spread the aesthetic experience. Actions aimed at increasing the 
awareness of residents about the places in which they live, enabling social involvement, beautifying the public sphere, popularising art, and providing artistic workshops for residents would be part of these activities.

\section{BIBLIOGRAPHY}

Adorno, Theodor W. and Horkheimer, Max. Dialectic of Enlightenment: Philosophical Fragments. Stanford: Stanford University Press 2002.

Arendt, Hannah. The Human Condition. Chicago: University of Chicago 1998.

Chmielewska, Katarzyna. "Podmiot jako utopia estetyczna 'Listy o estetycznym wychowaniu człowieka' Friedricha Schillera a 'Dziennik' Witolda Gombrowicza,” Pamiętnik Literacki XCV (2004), 7-20.

Crary, Jonathan. 24/7: Late Capitalism and the Ends of Sleep. London: Verso 2013.

Jay, Martin. Songs of experience: modern American and European variations on a universal theme. Berkeley and Los Angeles: University of California Press 2005.

Pańkow, Marcin. Hegel i pozór. Źródta i przedmiot dialektyki spekulatywnej. Warszawa: PWN 2014.

Prokopiuk, Jerzy. "Utopia i profecja, czyli dwie dusze Fryderyka Schillera." In Schiller, Fredrich. Listy o estetycznym wychowaniu czlowieka i inne rozprawy. Translated by Irena Krońska and Jerzy Prokopiuk. Warszawa: Czytelnik 1972.

Schiller, Friedrich. "What is, and to what end do we study, Universal History?" In Friedrich Schiller, Poet of Freedom. Vol. II, edited by Helga Zepp LaRouche. Washington, D. C.: Schiller Institute 1988.

Schiller, Friedrich. Aesthetical and Philosophical Essays. Vol. I. Boston: Francis A. Niccolls \& Co. 1902.

Wertz, William F. Jr. "A Reader's Guide to Schiller's 'Letters on the Aesthetical Education of Man'.” Fidelio vol. 14, no. 1-2, Spring-Summer (2005), 80-104. 